\title{
Vulnerability to Climate Change in Andhra Pradesh State, India
}

\author{
N.S. Praveen Kumar ${ }^{1 *}$, Y. Radha ${ }^{1}$, D.V. Subba Rao ${ }^{1}$, \\ V. Srinivasa Rao ${ }^{2}$ and T. Gopikrishna ${ }^{3}$ \\ ${ }^{1}$ Department of Agricultural Economics, Agricultural College, Bapatla, AP, India \\ ${ }^{2}$ Department of Statistics \&Computer Applications, Agricultural College, Bapatla, AP, India \\ ${ }^{3}$ Department of Agricultural Extension, ANGRAU, Guntur, AP, India \\ *Corresponding author
}

A B S T R A C T

\begin{tabular}{|l|}
\hline K e y w o r d s \\
Climate change, \\
Vulnerability index \\
\hline Article Info \\
\hline $\begin{array}{l}\text { Accepted: } \\
07 \text { October } 2018 \\
\text { Available Online: } \\
10 \text { November } 2018\end{array}$ \\
\hline
\end{tabular}

Climate change is essentially a long term phenomenon and is supposed to be gradual in its impact for most part. The vulnerability index of different districts was assessed using the long term data of 30 years for Andhra Pradesh state by employing Iyengar and Sudhershan methodology The results of the study indicated that out of the 13 districts of Andhra Pradesh, Anantapur district occupies first rank in term of vulnerability and was classified as very highly vulnerable district and East Godavari district was the less vulnerable district.

\section{Introduction}

Climate change (CC) will have multidimensional effect on mankind in terms of several socio-economic parameters. Among the different sectors, agriculture is the most important sector which will be severely affected by CC. Any scientific study on CC should take into account vulnerabilities of the different regions and then proceed to study its impacts on several sectors. IPCC (2007) defines vulnerability as 'the degree to which a system is susceptible to, and unable to cope with adverse effects of climate change, including climate variability and extremes. Vulnerability is a function of the character, magnitude and rate of climate change and variation to which a system is exposed, its sensitivity and its adaptive capacity. The present research is focused with an objective to assess the vulnerability indices of different districts of Andhra Pradesh.

\section{Materials and Methods}

To assess vulnerability to climate change of different districts of Andhra Pradesh, the secondary data were collected from different sources like Directorate of Economics and Statistics, Andhra Pradesh and Indian Meteorological Department, Hyderabad from the period during 1986-2015. The entire study period divided into three sub periods namely period I (1986-1995), period II (1996-2005) 
and period III (2006-2015). Iyengar and Sudarshan (1982) methodology was employed for the development of Composite Index of Vulnerability to Climate Change from multivariate data and it was used to rank the districts in terms of their economic performance. Vulnerability to climate change (CC) is a comprehensive multidimensional concept affected by large number of related indicators and hence it is necessary to measure the quantum of vulnerability by constructing a vulnerability index for each district.

This index is a composite one constructed on the basis of five indicators viz., i. demographic vulnerability with two components, ii. Climatic vulnerability with seven components iii. Agricultural vulnerability with thirteen components and iv. Occupational vulnerability with six components were employed for the construction of VI and the details of these five indicators are given in the appendix I. Using the methodology developed by Iyengar and Sudharshan (1982), a composite index from multivariate data was worked out and based on the index, all the districts were ranked in terms of their vulnerability to climate change and are categorized among the five different categories namely, less vulnerable, moderately vulnerable, vulnerable, highly vulnerable and very highly vulnerable. All the 13 districts in Andhra Pradesh were divided into three regions namely North Coastal (Visakhapatnam, Vizianagram and Srikakulam districts), South Coastal (Nellore, Prakasam, Guntur, Krishna, West Godavari and East Godavari districts) and Rayalaseema (Anatapur, Kurnool, kadapa, chittor districts) respectively.

\section{Appendix I}

Demographic vulnerability: There are two components involved in this index to explain the demographic patterns of the people living in respective district.
Density of population (persons per square kilometre)

Literacy rate (percentage)

Climatic vulnerability: This index tries to take into account basic climatic variability. It combines seven separate indices which are the variances of

Annual rainfall $\left(\mathrm{mm}^{2}\right)$

Kharif minimum temperature $\left({ }^{0} \mathrm{C}\right)$

Rabi minimum temperature $\left({ }^{0} \mathrm{C}\right)$

Summer minimum temperature $\left({ }^{0} \mathrm{C}\right)$

Kharif maximum temperature $\left({ }^{0} \mathrm{C}\right)$

Rabi maximum temperature $\left({ }^{0} \mathrm{C}\right)$

Summer maximum temperature $\left({ }^{0} \mathrm{C}\right)$

Agricultural vulnerability: This includes the following variables to predict the vulnerability related to agricultural activities.

Productivity of total food grains (kg/ha)

Productivity of rice $(\mathrm{kg} / \mathrm{ha})$

Productivity of jowar $(\mathrm{kg} / \mathrm{ha})$

Productivity of maize $(\mathrm{kg} / \mathrm{ha})$

Productivity of cotton $(\mathrm{kg} / \mathrm{ha})$

Productivity of groundnut $(\mathrm{kg} / \mathrm{ha})$

Productivity of red gram (kg/ha)

Productivity of sugarcane $(\mathrm{kg} / \mathrm{ha})$

Cropping intensity (per cent)

Irrigation intensity (per cent)

Forest area (Per cent to geographical area)

Net area sown (hectares)

Livestock population (no. per ha of gross cropped area)

Occupational vulnerability: Six indicators were taken to calculate the vulnerability related to occupational characteristics of people and all these variables were converted into per hectare of net sown area.

Number of cultivators

Total main workers

Agricultural labourers 
Marginal workers

Industrial workers

Non workers

\section{Measuring vulnerability}

A brief discussion of the Iyengar and Sudarshan (1982) methodology for the development of composite index of vulnerability assumed that there are $M$ regions/districts, $\mathrm{K}$ components for vulnerability and $C_{k}$ is the number of variables in component $k$ so that $k_{i c} X$ is the value of the variable $c_{k}$ of the $k^{\text {th }}$ component for the $i^{\text {th }}$ region. First, these values of vulnerability indicators which may be in different units of measurement are standardized. When the observed values are related positively to the vulnerability, the standardization is achieved by employing the formula

$$
y_{i d}=\left(\begin{array}{ll}
X_{i d}-\operatorname{Min} & X_{i d}
\end{array}\right) /\left(\operatorname{Max} X_{i d}-\operatorname{Min} X_{i d}\right)
$$

When the values of $X_{\text {id }}$ are negatively related to the vulnerability, the standardized values would be computed by

$y_{i d}=\left(\begin{array}{ll}\operatorname{Max} & X_{i d}-X_{i d}\end{array}\right) /\left(\operatorname{Max} X_{i d}-\operatorname{Min} X_{i d}\right)$

Where $\operatorname{Min} X_{i d}$ and $\operatorname{Max} X_{i d}$ are the minimum and maximum of $\left(X_{i 1}, X_{i 2}, \ldots . X_{i n}\right)$ respectively. Obviously these standardized indices lie between 0 and 1 .

The level or stage of development of $d^{t h}$ zone is assumed to be a linear sum of ${ }^{y_{i d}}$ as

$\overline{y_{d}}=\sum_{i=1}^{m} w_{i} y_{i d}$

Where W's $\left(0<w<1\right.$ and $\left.\sum_{i=1}^{n} w_{i}=1\right)$ are the weights determined by

$$
w_{i}=\frac{k}{\sqrt{\operatorname{var}\left(y_{i}\right)}}
$$

$$
k=\left\lceil\sum_{i=1}^{n} \frac{1}{\sqrt{\operatorname{Var}\left(y_{i}\right)}}\right\rfloor^{-1}
$$

The choice of the weights in this manner would ensure that large variation in any one of the indicators would not unduly dominate the contribution of the rest of the indicators and distort inter zone comparisons.

For classificatory purposes, a simple ranking of the zone indices viz., ${ }^{y_{d}}$ would be enough. However for a meaningful characterization of the different stages of vulnerability, suitable fractile classification from an assumed distribution is needed. Probability distribution which is widely used is the Beta distribution. This distribution is defined by

$f(z)=x^{a-1}(1-x)^{b-1} / b(a, b), 0 £ x £ 1$ and $a, b>0$.

This distribution has two parameters $a$ and $b$. They can be estimated by using the method given by Iyengar and Sudharshan (1982). The Beta distribution is skewed. Let $\left(0, z_{1}\right),\left(z_{1}, z_{2}\right),\left(z_{2}, z_{2}\right),\left(z_{3}, z_{4}\right)$ and $\left(z_{4}, 1\right)$ be the linear intervals and each interval has the same probability weight of 20 per cent. These fractile intervals can be used to characterize the various stages of vulnerability.

\section{Results and Discussion}

The vulnerability indices for all the 13 districts were constructed as per the methodology described earlier. Based on the indices, the districts were ranked and the rankings are given in Table 1. For this Beta probability distribution was fitted to the observed indices and the percentile values at $20,40,60$, and 80 were taken as cut-off points 
for the five groups. This resulted in the classification as given in Tables 2, 3 and 4.

The Vulnerability Indices were analysed for all the districts of Andhra Pradesh state for three different periods, viz., 1986-1995, 19962005 and 2006-2015.

District-wise vulnerability to climate change of Andhra Pradesh during 19861995

As revealed by the results of the Table 1 it is observed that in Andhra Pradesh, Anantapur district ranked first and East Godavari District ranked last in the overall vulnerability to climate change for period I during 1986 to1995. So, the Anantapur district was regarded as the most vulnerable to climate change and East Godavari district as the least vulnerable to climate change with the Vulnerability Index values ranging from 0.627 for Anantapur to 0.415 for East Godavari districts during the period.(Kumar et al., 2014).

The Table 1 also depicts the comparative analysis of Vulnerabilty Index among the three regions of Andhra Pradesh. In North coastal region Vizianagaram was highly vulnerable followed by Visakhapatnam and Srikakulam, whereas in South coastal region Prakasam was highly vulnerable followed by
Krishna, West Godavari, Guntur, Nellore and East Godavari districts. In Rayalaseema region, Anantapur district was highly vulnerable followed by Kadapa, Chittor and Kurnool.

District-wise vulnerability to climate change of Andhra Pradesh during 19962005

From the results of the Table 1, it is revealed that Anantapur district from Rayalaseema region ranked first and East Godavari district from South Coastal region ranked last in the overall Vulnerability Index to climate change for period II during 1996 to 2005. It is implied that Anantapur district was the most vulnerable district to climate change in Andhra Pradesh during period II and East Godavari was the least vulnerable district with the index values varying from 0.603 to 0.393 respectively (Hiremath et al., 2015).

In North Coastal region, Srikakulam was highly vulnerable followed by Visakhapatnam and Vizianagaram districts where as in South Coastal region, Prakasam district was highly vulnerable followed by West Godavari, Nellore, Krishna, Guntur and East Godavari districts. In Rayalaseema region, Anantapur district was highly vulnerable followed by Kadapa, Chittor and Kurnool districts.

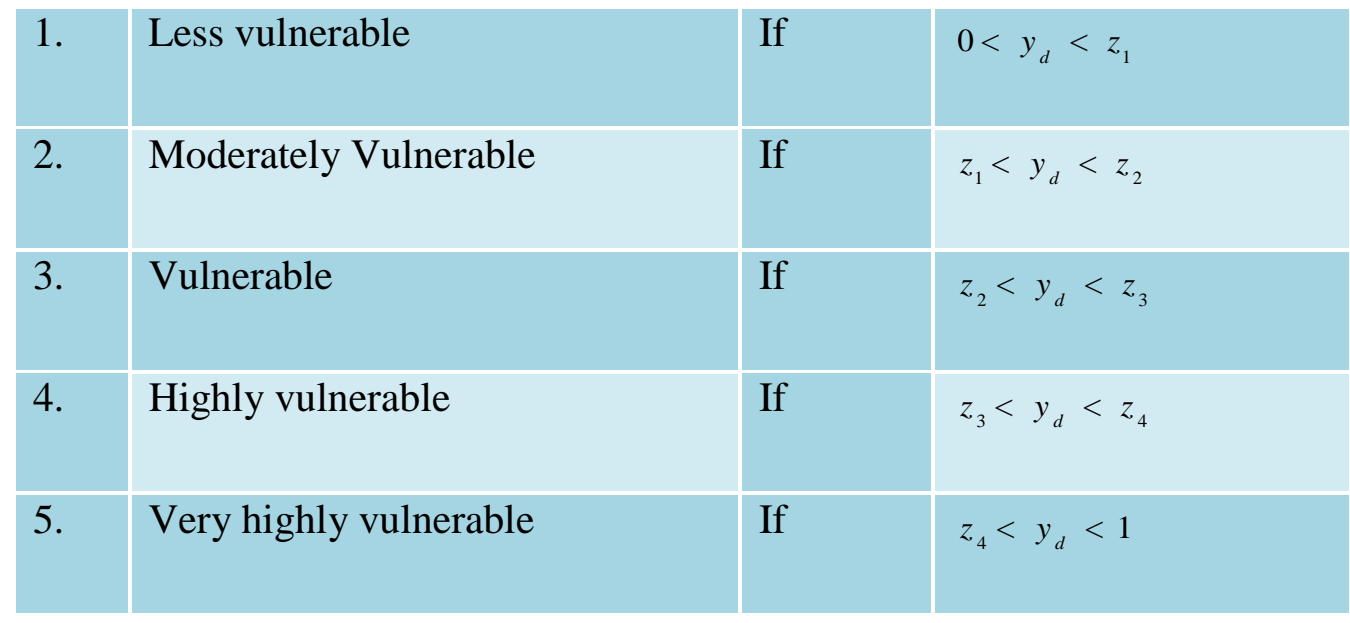


Appendix II Functional relationship of different variables with vulnerability

\begin{tabular}{|c|c|c|c|}
\hline $\begin{array}{l}\text { S. } \\
\text { No. }\end{array}$ & Component & Indicators & $\begin{array}{l}\text { Functional } \\
\text { relationship }\end{array}$ \\
\hline \multirow[t]{2}{*}{1} & \multirow[t]{2}{*}{ Demographic(2) } & (a)Density of population (persons per sqkm) & $\uparrow$ \\
\hline & & (b)Literacy rate (per cent) & $\downarrow$ \\
\hline \multirow[t]{7}{*}{2} & \multirow[t]{7}{*}{ Climatic (7) } & (a) Variance of annual rainfall $\left(\mathrm{mm}^{2}\right)$ & $\uparrow$ \\
\hline & & (b)Variance of kharif minimum temperature $\left({ }^{0} \mathrm{C}\right)$ & $\uparrow$ \\
\hline & & (c) Variance of rabi minimum temperature $\left({ }^{0} \mathrm{C}\right)$ & $\uparrow$ \\
\hline & & (d) Variance of summer minimum temperature $\left({ }^{0} \mathrm{C}\right)$ & $\uparrow$ \\
\hline & & (e) Variance of kharif maximum temperature $\left({ }^{0} \mathrm{C}\right)$ & $\uparrow$ \\
\hline & & (f) Variance of rabi maximum temperature $\left({ }^{0} \mathrm{C}\right)$ & $\uparrow$ \\
\hline & & (g) Variance of summer maximum temperature $\left({ }^{0} \mathrm{C}\right)$ & $\uparrow$ \\
\hline \multirow[t]{13}{*}{3} & \multirow[t]{13}{*}{ Agricultural(13) } & (a) Productivity of total food grains(kg/ha) & $\downarrow$ \\
\hline & & (b) Productivity of rice $(\mathrm{kg} / \mathrm{ha})$ & $\downarrow$ \\
\hline & & (c) Productivity of jowar (kg/ha) & $\downarrow$ \\
\hline & & (d) Productivity of maize (kg/ha) & $\downarrow$ \\
\hline & & (e) Productivity of cotton $(\mathrm{kg} / \mathrm{ha})$ & $\downarrow$ \\
\hline & & (f) Productivity of groundnut (kg/ha) & $\downarrow$ \\
\hline & & (g) Productivity of red gram (kg/ha) & $\downarrow$ \\
\hline & & (h) Productivity of sugarcane (kg/ha) & $\downarrow$ \\
\hline & & (i) Cropping intensity (per cent) & $\downarrow$ \\
\hline & & (j) Irrigation intensity (per cent) & $\downarrow$ \\
\hline & & (k) Forest area (Per cent to geographical area) & $\downarrow$ \\
\hline & & (1) Net area sown (hectares) & $\downarrow$ \\
\hline & & $\begin{array}{l}\text { (m)Livestock population(no per ha of gross cropped } \\
\text { area) }\end{array}$ & $\downarrow$ \\
\hline \multirow[t]{6}{*}{4} & \multirow[t]{6}{*}{ Occupational(6) } & (a) Total main workers (no per ha of net area sown) & $\downarrow$ \\
\hline & & (b) No. of cultivators (no per ha of net area sown) & $\downarrow$ \\
\hline & & (c) Agricultural labourers (no per ha of net area sown) & $\downarrow$ \\
\hline & & (d) Industrial workers (no per ha of net area sown) & $\downarrow$ \\
\hline & & (e) Marginal workers (no per ha of net area sown) & $\downarrow$ \\
\hline & & (f) Non-workers (no per ha of net area sown) & $\uparrow$ \\
\hline
\end{tabular}

Note: The symbol $\uparrow \downarrow$ indicates that vulnerability of the region increases (decreases) with the increase (decrease) in the value of the indicator. 
Table.1 District-wise vulnerability index of Andhra Pradesh state

\begin{tabular}{|c|c|c|c|c|c|c|c|}
\hline \multirow[t]{2}{*}{ S. No. } & \multirow[t]{2}{*}{ District } & \multicolumn{2}{|c|}{$\begin{array}{c}\text { Period I } \\
(1986-1995)\end{array}$} & \multicolumn{2}{|c|}{$\begin{array}{c}\text { Period II } \\
(1996-2005)\end{array}$} & \multicolumn{2}{|c|}{$\begin{array}{c}\text { Period II } \\
(2006-2015)\end{array}$} \\
\hline & & $\begin{array}{c}\text { Overall } \\
\text { VI }\end{array}$ & Rank & $\begin{array}{c}\text { Overall } \\
\text { VI }\end{array}$ & Rank & $\begin{array}{c}\text { Overall } \\
\text { VI }\end{array}$ & Rank \\
\hline 1 & Srikakulam & 0.551 & 4 & 0.507 & 6 & 0.598 & 3 \\
\hline 2 & Vizianagaram & 0.572 & 2 & 0.571 & 2 & 0.584 & 4 \\
\hline 3 & Visakhapatnam & 0.554 & 3 & 0.536 & 5 & 0.555 & 5 \\
\hline 4 & East Godavari & 0.415 & 13 & 0.393 & 13 & 0.431 & 12 \\
\hline 5 & West Godavari & 0.502 & 8 & 0.453 & 9 & 0.474 & 9 \\
\hline$\overline{6}$ & Krishna & 0.523 & 7 & 0.435 & 11 & 0.490 & 7 \\
\hline 7 & Guntur & 0.426 & 10 & 0.420 & 12 & 0.442 & 11 \\
\hline 8 & Prakasam & 0.525 & 6 & 0.478 & 8 & 0.484 & 8 \\
\hline 9 & Nellore & 0.425 & 11 & 0.447 & 10 & 0.427 & 13 \\
\hline 10 & Kadapa & 0.418 & 12 & 0.562 & 3 & 0.555 & 6 \\
\hline 11 & Kurnool & 0.527 & 5 & 0.494 & 7 & 0.638 & 2 \\
\hline 12 & Anantapur & 0.627 & 1 & 0.603 & 1 & 0.651 & 1 \\
\hline 13 & Chittor & 0.428 & 9 & 0.547 & 4 & 0.447 & 10 \\
\hline
\end{tabular}

Table.2 Classification of districts into different degrees of vulnerability during period I (1986- 1995)

\begin{tabular}{|c|l|l|l|l|l|} 
S. & \multicolumn{1}{|c|}{$\begin{array}{c}\text { Less } \\
\text { Vulnerable } \\
(\mathbf{0}-\mathbf{0 . 4 6 0 )}\end{array}$} & $\begin{array}{c}\text { Moderately } \\
\text { Vulnerable } \\
(\mathbf{0 . 4 6 0 - 0 . 4 9 9 )}\end{array}$ & $\begin{array}{c}\text { Vulnerable } \\
(\mathbf{0 . 4 9 9 - 0 . 5 3 3 )}\end{array}$ & $\begin{array}{c}\text { Highly } \\
\text { Vulnerable } \\
(\mathbf{0 . 5 3 3 - 0 . 5 7 2})\end{array}$ & $\begin{array}{c}\text { Very Highly } \\
\text { Vulnerable } \\
(\mathbf{0 . 5 7 2 - 1})\end{array}$ \\
\hline $\mathbf{1}$ & $\begin{array}{l}\text { East } \\
\text { Godavari }\end{array}$ & Guntur & $\begin{array}{l}\text { West } \\
\text { Godavari }\end{array}$ & Krishna & Vizianagaram \\
\hline $\mathbf{2}$ & Nellore & & Prakasam & Srikakulam & Ananatapur \\
\hline $\mathbf{3}$ & Kadapa & & & Visakhapatnam & \\
\hline $\mathbf{4}$ & Chittor & & & Kurnool & \\
\hline
\end{tabular}

Table.3 Classification of districts into different degrees of vulnerability during period II (1996- 2005)

\begin{tabular}{|c|c|c|c|c|c|}
\hline S. No. & $\begin{array}{c}\text { Less } \\
\text { Vulnerable } \\
(\mathbf{0}-\mathbf{0 . 4 4 0 )}\end{array}$ & $\begin{array}{l}\text { Moderately } \\
\text { Vulnerable } \\
(0.440-0.479)\end{array}$ & $\begin{array}{c}\text { Vulnerable } \\
(0.479-0.512)\end{array}$ & $\begin{array}{c}\text { Highly } \\
\text { Vulnerable } \\
(0.512-0.550)\end{array}$ & $\begin{array}{c}\text { Very Highly } \\
\text { Vulnerable } \\
(\mathbf{0 . 5 5 0}-\mathbf{1})\end{array}$ \\
\hline 1 & East Godavari & Nellore & Kurnool & Srikakulam & Vizianagaram \\
\hline 2 & Guntur & $\begin{array}{l}\text { West } \\
\text { Godavari }\end{array}$ & & Visakhapatnam & Ananatapur \\
\hline 3 & Krishna & Prakasam & & Chittor & Kadapa \\
\hline
\end{tabular}


Table.4 Classification of districts into different degrees of vulnerability for the period III (2006- 2015)

\begin{tabular}{r|l|c|l|l|l|} 
S. & \multicolumn{1}{|c|}{$\begin{array}{c}\text { Less } \\
\text { Vulnerable } \\
(\mathbf{0 - 0 . 4 5 )}\end{array}$} & $\begin{array}{c}\text { Moderately } \\
\text { Vulnerable } \\
(\mathbf{0 . 4 5 - 0 . 5 0 0 )}\end{array}$ & $\begin{array}{c}\text { Vulnerable } \\
(\mathbf{0 . 5 0 0 -} \\
\mathbf{0 . 5 4 2})\end{array}$ & $\begin{array}{c}\text { Highly } \\
\text { Vulnerable } \\
(\mathbf{0 . 5 4 2 - 0 . 5 8 9 )})\end{array}$ & $\begin{array}{c}\text { Very Highly } \\
\text { Vulnerable } \\
(\mathbf{0 . 5 8 9 - 1})\end{array}$ \\
\hline $\mathbf{1}$ & East Godavari & West Godavari & Krishna & Kadapa & Kurnool \\
\hline $\mathbf{2}$ & Nellore & Prakasam & & Visakhapatnam & Ananatapur \\
\hline $\mathbf{3}$ & Guntur & & & Vizianagaram & Srikakulam \\
\hline $\mathbf{4}$ & Chittor & & & & \\
\hline
\end{tabular}

District-wise vulnerability to climate change of Andhra Pradesh for 2006-2015

The results of Table1 further revealed that Anantapur district ranked first and Nellore district ranked last in the overall Vulnerability Index to climate change for period III during 2006-2015. Thus, Anantapur was considered as the most vulnerable district and Nellore district as the least vulnerable, whose Vulnerability Index values varied from 0.651 to 0.426 respectively during period III.

In North Coastal region, Srikakulam was highly vulnerable followed by Vizianagaram and Visakhapatnam districts where as in South Coastal region, Krishna district was highly vulnerable followed by Prakasam, West Godavari, Guntur, East Godavari and Nellore districts. In Rayalaseema region, Anantapur district was highly vulnerable followed by Kurnool, Kadapa and Chittor districts.

\section{Classification of the districts of Andhra Pradesh based on vulnerability}

The results pertaining to classification of the districts into different degrees of vulnerability for the periods 1986-1995, 1996-2005 and 2006- 2015 are given in Tables 3, 4, 5 respectively. It is seen from Table2 that the districts viz., Vizianagaram and Anantapur were very highly vulnerable and Krishna, Srikakulam, Visakhapatnam and Kurnool were highly vulnerable districts. West Godavari and Prakasam districts were vulnerable. During the same period, Guntur was the moderately vulnerable district. East Godavari, Nellore, Kadapa and Chittoor were the less vulnerable districts in period I.

In period II of Table 3 the districts of Vizianagaram, Kadapa and Anantapur were very highly vulnerable and Srikakulum, Visakhapatnam and Chittor were highly vulnerable. Kurnool was found to be the vulnerable district. The districts Nellore, West Godavari and Prakasam were moderately vulnerable while East Godavari, Guntur and Krishna were less vulnerable districts.

In period III, the districts of Kurnool, Anantapur and Srikakulam were very highly vulnerable and Kadapa, Visakhapatnam and Vizianagaram districts were found to be highly vulnerable. Krishna district was the vulnerable district (Table 4). West Godavari and Prakasm districts were the moderately vulnerable districts while East Godavari, Nellore, Guntur and Chittor were less vulnerable districts.

Among the thirteen districts of Andhra Pradesh, Anantapur district was very highly vulnerable and East Godavari district was less vulnerable during period I (1986-1995), period II (1996-2005) and period III (20062015). 


\section{References}

Hiremath, D.B., Shiyani, R.L and Mundinamani, S.M. 2015. Vulnerability of drylands of Saurashtra (Gujarat) to climate change: A socioeconomic analysis. Karnataka Journal of Agricultural Science. 28(5): 735-740.

IPCC 2007. Climate change: impacts, adaptation and vulnerability: Working Group II Contribution to the Intergovernmental Panel on Climate Change: Summary for Policymakers. IPCC Secretariat: Geneva, Switzerland.
Iyengar, N.S and Sudarshan, P. 1982. A method of classifying regions from multivariate data. Economic and Political Weekly. Special Article: 204852.

Kumar, P.N.S., Paul, K.S.R and Rao, D.V.S. 2014. Assess the vulnerability of climate change in Krishna river basin of Andhra Pradesh. International Journal of Development Research. 4(5): 10591061.

\section{How to cite this article:}

Praveen Kumar, N.S., Y. Radha, D.V. Subba Rao, V. Srinivasa Rao and Gopikrishna, T. 2018. Vulnerability to Climate Change in Andhra Pradesh State, India. Int.J.Curr.Microbiol.App.Sci. 7(11): 495-502. doi: https://doi.org/10.20546/ijcmas.2018.711.059 